ISSN 1678-3921

Journal homepage: www.embrapa.br/pab

For manuscript submission and journal contents, access: www.scielo.br/pab
Enderson Petrônio de Brito Ferreira ${ }^{(1 凶)}$ (iD , Osmira Fátima da Silva ${ }^{(1)}$ (iD) and

Alcido Elenor Wander ${ }^{(1)}$ (iD

(1) Embrapa Arroz e Feijão, Rodovia GO-462, $\mathrm{Km}$ 12, Fazenda Capivara, Zona Rural, Caixa Postal 179, CEP 75375-000 Santo Antônio de Goiás, GO, Brazil. E-mail: enderson.ferreira@embrapa.br, osmira.silva@embrapa.br, alcido.wander@embrapa.br

$\bowtie$ Corresponding author

Received

June 14, 2019

Accepted

May 20, 2020

How to cite

FERREIRA, E.P. de B.; SILVA, O.F. da;

WANDER, A.E. Economics of rhizobia and azospirilla co-inoculation in irrigated common bean in commercial and family farming. Pesquisa Agropecuária Brasileira, v.55, e01532, 2020. DOI: https://doi.org/10.1590/ S1678-3921.pab2020.v55.01532.

\section{Economics of rhizobia and azospirilla co-inoculation in irrigated common bean in commercial and family farming}

\begin{abstract}
The objective of this work was to evaluate the economic viability of the co-inoculation with Rhizobium tropici and Azospirillum brasilense in the Pérola cultivar of common bean (Phaseolus vulgaris), under sprinkler irrigation, in commercial and family farming in the states of Minas Gerais and Goiás, Brazil. For the analysis of economic viability, data from seven field experiments that evaluated the agronomic performance of common bean co-inoculated with $R$. tropici and $A$. brasilense, at six different sites, in three cropping seasons, were used. In these experiments, the treatments consisted of: non-inoculated control; N-fertilizer treatment; and different doses and forms of inoculum application. The economic analysis was performed based on market prices and indices as a function of the grain production of the different treatments. Economic viability was analyzed using the partial budgeting method. The best economic performance was obtained with the treatment $R$. tropici + three doses of A. brasilense sprayed on plants, which resulted in return rates of $90 \%$ in Goiás and $114 \%$ in Minas Gerais, for commercial farming, and of $13 \%$ in Goiás for family farming. For commercial and family farming, the production cost when using $\mathrm{N}$ fertilizer is 5.0 and $8.5 \%$ higher, respectively, than that with the co-inoculation of two doses of $R$. tropici and three doses of $A$. brasilense.
\end{abstract}

Index terms: Phaseolus vulgaris, market price, partial budgeting, profit.

\section{Economia da coinoculação de rizóbio e azospirilo em feijão-comum irrigado em produção comercial e familiar}

Resumo - O objetivo deste trabalho foi avaliar a viabilidade econômica da coinoculação de Rhizobium tropici e Azospirillum brasilense na cultivar Pérola de feijão-comum (Phaseolus vulgaris), sob irrigação, em produção comercial e familiar, nos estados de Minas Gerais e Goiás. Para a avaliação da viabilidade econômica, foram utilizados dados de sete experimentos de campo que avaliaram o desempenho agronômico do feijoeiro-comum coinoculado com $R$. tropici e $A$. brasilense, em seis locais diferentes, em três anos agrícolas. Nesses experimentos, os tratamentos consistiram de: controle, sem inoculação; fertilização com nitrogênio; e diferentes doses e formas de aplicação dos inóculos. A análise econômica foi realizada com base nos preços e nos índices de mercado, em função da produção de grãos dos diferentes tratamentos. Já a viabilidade econômica foi avaliada com o método orçamentário parcial. O melhor desempenho econômico foi obtido com o tratamento $R$. tropici + três doses de A. brasilense pulverizado nas plantas, o que resultou em taxa de retorno de $90 \%$ em Goiás e de $114 \%$ em Minas 
Gerais, nas produções comerciais, e de 13\% em Goiás, nas produções familiares. Na agricultura comercial e familiar, o custo de produção com uso de fertilizante nitrogenado é 5,0 e $8,5 \%$ superior, respectivamente, ao da coinoculação de duas doses de $R$. tropici e três de $A$. brasilense.

Termos para indexação: Phaseolus vulgaris, preço de mercado, orçamento parcial, lucro.

\section{Introduction}

Common bean (Phaseolus vulgaris L.) is grown in three annual crop seasons in Brazil. The first is during spring-summer, mainly in the Southern and Southeastern regions of the country. The second occurs during summer-autumn in the Southern, Southeastern, and Midwestern regions. Finally, the third is during winter, in tropical areas under sprinkler irrigation, especially in the states of Minas Gerais, São Paulo, Goiás, Distrito Federal, Tocantins, Mato Grosso, and in the western region of Bahia (Silva et al., 2012).

According to Embrapa Arroz e Feijão (2020), in 2017, common bean production in the first and second crop seasons was 1.20 and 0.88 million tons, respectively. The area harvested with common bean was 723.1 and 759.6 thousand hectares, respectively, with yields of 1,667 and $1,159 \mathrm{~kg} \mathrm{ha}^{-1}$, in the first and second harvests. The irrigated crop produced 539 thousand tons of common bean, harvested in 207 thousand hectares, with an average yield of $2,598 \mathrm{~kg} \mathrm{ha}^{-1}$. The irrigated common bean crop represents 25.9 and $14.0 \%$ of the common bean production and area harvested in the country, respectively.

In this context, the increasing use of new technologies and cultural practices is becoming necessary in order to obtain greater yields to guarantee a more profitable common bean production system for producers, who usually face soil and phytosanitary problems inherent to each production system, high production costs, product price fluctuations, and an increasingly demanding market. Therefore, not only the adoption of new common bean varieties with proven high yields, but also the proper management of crops, is key to the success of common bean cultivation.

Among the technological innovations to improve the performance of common bean crops and to obtain a higher profitability at reduced costs, stand out some inoculant strains of proven effectiveness in biological nitrogen fixation and in promoting plant growth, such as Rhizobium tropici and Azospirillum brasilense, respectively. Due to these characteristics, these inoculants may allow reductions in the use of nitrogen fertilizer in the common bean crop and promote the growth of plants (Brito et al., 2015; Souza \& Ferreira, 2017).

Studies about the efficiency of nitrogen fertilization on common bean plant growth and yield have already been carried out (Argaw et al., 2015; Sorato et al., 2017). Nitrogen fertilization has been coupled with the inoculation with biofertilizers, such as the Semia 4077 (CIAT 899) and Semia 4080 (PRF 81) commercial strains (Brito et al., 2015). These researches highlight the importance of having knowledge of the variety and the conditions of development of the crop to produce grains. However, the obtained results are still controversial since the grain yield obtained with fertilization with $20 \mathrm{~kg} \mathrm{ha}^{-1} \mathrm{~N}$, together with the inoculation with the CIAT 899 strain of $R$. tropici, was equivalent to that when using either up to $80 \mathrm{~kg} \mathrm{ha}^{-1} \mathrm{~N}$ (Soares et al., 2016) or $160 \mathrm{~kg} \mathrm{ha}^{-1} \mathrm{~N}$ (Brito et al., 2011).

Contrastingly, Peres (2016) found that the coinoculation with $R$. tropici and $A$. brasilense, the inoculation with $R$. tropici, the inoculation with $A$. brasilense associated with $40 \mathrm{~kg} \mathrm{ha}^{-1} \mathrm{~N}$ as top dressing, and only the application of $80 \mathrm{~kg} \mathrm{ha}^{-1} \mathrm{~N}$ as top dressing do not provide yield increases, when compared with the control without inoculation and with $40 \mathrm{~kg} \mathrm{ha}^{-1}$ $\mathrm{N}$ as top dressing. However, Souza \& Ferreira (2017) observed that the co-inoculation with $R$. tropici and $A$. brasilense resulted in yield increases of about 5 and $26 \%$, respectively, in comparison with the application of $80 \mathrm{~kg} \mathrm{ha}^{-1} \mathrm{~N}$ and with a single inoculation with R. tropici.

Although there are reports of the advantages of the use of co-inoculation over nitrogen fertilizers, there is still no known economic analysis available.

The objective of this work was to evaluate the economic viability of the co-inoculation with Rhizobium tropici and Azospirillum brasilense in the Pérola cultivar of common bean, under sprinkler irrigation, in commercial and family farming in the states of Minas Gerais and Goiás, Brazil.

\section{Materials and Methods}

The analysis of the economic viability of the co-inoculation technology in common bean was 
based on data from seven field experiments reported in Souza \& Ferreira (2017), which were carried out in six different Brazilian municipalities (Cristalina, Goianésia, Itaberaí, and Santo Antônio de Goiás in the state of Goiás; and Paracatu and Unaí in the state of Minas Gerais) in three crop seasons (2013, 2014, and 2015). The cropping system was commercial production farming, with irrigation via a central pivot sprinkler, in all municipalities, except in Goianésia, where it was family farming, with sprinkler irrigation using electric pumping.

In these field experiments, the aim was to evaluate the agronomical performance of the Pérola common bean cultivar, of the "carioca" commercial grain type, when co-inoculated with $R$. tropici (Rt) and A. brasilense (Ab). The treatments consisted of: non-inoculated control (NI), $80 \mathrm{~kg} \mathrm{ha}^{-1} \mathrm{~N}$ fertilizer (NfT) as urea (178 $\mathrm{kg} \mathrm{ha}^{-1}$ ), two doses of Rt in seeds, two doses of Rt in seeds plus one dose of $\mathrm{Ab}$ in seeds (Rt+Ab1s), two doses of Rt in seeds plus two doses of $A b$ in seeds $(R t+A b 2 s)$, two doses of Rt in seeds plus two doses of Ab sprayed on plants $(\mathrm{Rt}+\mathrm{Ab} 2 \mathrm{p})$, and two doses of Rt in seeds plus three doses of Ab sprayed on plants (Rt+Ab3p). Economic viability was calculated considering the operational costs related to: the desiccation of the area, with $4.0 \mathrm{~L} \mathrm{ha}^{-1}$ glyphosate by mechanized spraying; soil fertilization, consisting of $300 \mathrm{~kg} \mathrm{ha}^{-1}$ of the 00-30-10 N-P ${ }_{2} \mathrm{O}_{5}-\mathrm{K}_{2} \mathrm{O}$ formula; seed treatment, with $0.15 \mathrm{~L} \mathrm{ha}^{-1}$ of the thiamethoxam insecticide and 0.06 $\mathrm{kg} \mathrm{ha}^{-1}$ of the carboxin + thiram fungicides; ant control, with $0.50 \mathrm{~kg} \mathrm{ha}^{-1}$ of the sulfluramid formicide; weed control, with $0.30 \mathrm{~L} \mathrm{ha}^{-1}$ of the clethodim herbicide; phytosanitary treatments, with 0.40 and $1.00 \mathrm{~L} \mathrm{ha}^{-1}$ of the abamectin and chlorpyrifos insecticides, respectively, and with 1.50 and $1.50 \mathrm{~L} \mathrm{ha}^{-1}$ of the procymidone and triphenyltin hydroxide fungicides; irrigation via central pivot, estimated at $1,000 \mathrm{kWh} \mathrm{ha}^{-1}$ of electric energy consumed for an average common bean yield of 49 bags of $60 \mathrm{~kg} \mathrm{ha}^{-1}$ each; mechanized harvest, carried out with the Ceiflex 3000T reaper machine (Indústrias Colombo, Pindorama, SP, Brazil); grain collection, threshing, and bagging, using the Master Grãos threshing machine (Miac Máquinas Agrícolas, Pindorama, SP, Brazil); and post-harvest costs, including grain reception, drying, cleaning, and storage, calculated as $1.8 \%$ of the production value.

To calculate the total cost of production, other additional costs were also taken into account, such as those with: Programa de Garantia da Atividade Agropecuária, the Brazilian agricultural and livestock insurance program; private technical assistance, totalizing $2 \%$ of the operational costs; and social security, obtained from Instituto Nacional de Seguridade Social, the national institute of social security, and calculated as $2.2 \%$ over the sales of the production.

Calculations were performed similarly for both the commercial and family farming systems; the difference was that, for the later, costs with sprinkler irrigation were included. This cost was estimated at $277 \mathrm{kWh} \mathrm{ha}^{-1}$ of electric energy consumed for an average common bean yield of 25 bags of $60 \mathrm{~kg} \mathrm{ha}^{-1}$ each.

The economic analysis of the cropping system was performed according to Guiducci et al. (2012), considering the economic surplus proposed by Avila et al. (2008), assessments of the technical coefficients of the Pérola common bean cultivar, and field visits to the regions with the studied technology by the producers, technical-assistance technicians, and technical staff of Embrapa Arroz e Feijão.

The technical coefficients of common bean were processed on a production cost worksheet, prepared in Microsoft Excel, and crossed with the average unit prices of the production factors in the markets of the states of Goiás and Minas Gerais for each study year. Factor and product prices for 2013 and 2014 were updated according to the general price index of Fundação Getúlio Vargas (FGV), for which the base was April $2015=1.00$, and to the price received by the common bean producers at the time of harvest, for which the base was September $2015=1.00$.

The economic balance of the cropping system was determined based on the partial budgeting method, where the unit costs of the production factors are calculated, focusing on the increase in the gross revenue coming from the additional cost of the impacting variable, which, in this case, is the inoculant in different dosages and number of applications. By the analysis of the marginal benefit (Baye, 2010), a cropping system is adopted based on the economic value of the co-inoculation, i.e., when the additional revenues are higher than the additional costs of the technology.

Data, except those of production costs, were first subjected to tests of normality and homogeneity of variances for each variable and then to the analysis of variance. When a statistically significant value 
was confirmed in the F-test, at 5\% probability, mean values were compared by Scott-Knott's test, also at 5\% probability, using the Sisvar software (Ferreira, 2011).

\section{Results and Discussion}

The grain yield of the common bean crop grown in commercial farming varied from 2,351.15 to 3,149.35 $\mathrm{kg} \mathrm{ha}^{-1}$ in the state of Goiás and from 3,378.30 to 4,036.22 $\mathrm{kg} \mathrm{ha}^{-1}$ in Minas Gerais. The average of the seven treatments evaluated was approximately 47 and 60 bags of $60 \mathrm{~kg} \mathrm{ha}^{-1}$ each for the states of Goiás and Minas Gerais, respectively (Table 1). For family farming in Goiás, grain yield was lower, varying from $1,499.65$ to $2,349.55 \mathrm{~kg} \mathrm{ha}^{-1}$, which is equivalent to 24.99 and 39.16 bags of $60 \mathrm{~kg} \mathrm{ha}^{-1}$, respectively (Table 2).

These results showed that grain yield differed significantly between the commercial and family farming systems. While the average grain yield of common bean under commercial farming was about 54 bags of $60 \mathrm{~kg} \mathrm{ha}^{-1}$, under family farming, it was approximately 35 bags of $60 \mathrm{~kg} \mathrm{ha}^{-1}$. This difference is explained by the technological level of each production system. In family farming, common bean production and supply to markets by the smallholders is constrained, mainly by the lack of productive assets, lack of improved varieties, and inadequate use of fertilizers (Birachi et al., 2011). In commercial farming systems, however, cutting-edge technologies are adopted, such as geo-referred mechanization, lastgeneration agricultural inputs, and cultivars with a high productive potential (Farinelli \& Lemos, 2010). Therefore, due to these differences, the productivity of commercial farming systems is higher than that of family farming.

In the state of Goiás, the Rt+Ab3p treatment resulted in about 53 bags of $60 \mathrm{~kg} \mathrm{ha}^{-1}$ each, which shows an increase of 4 bags of $60 \mathrm{~kg} \mathrm{ha}^{-1}$ in comparison with NfT. In the state of Minas Gerais, grain yield exceeded 4 tons per hectare (67.27 bags of $\left.60 \mathrm{~kg} \mathrm{ha}^{-1}\right)$ in $\mathrm{Rt}+\mathrm{Ab} 3 \mathrm{p}$, resulting in about 9 bags of $60 \mathrm{~kg} \mathrm{ha}^{-1}$ more than those of the NfT treatment (Table 1). Several authors reported the positive effect of the co-inoculation with $R$. tropici and $A$. brasilense on the grain yield of common bean (Hungria et al., 2013; Souza \& Ferreira, 2017), which is probably related to the synergy of these microorganisms when combined, leading to better results than those of single inoculation (Bárbaro et al., 2008).

The production costs of the common bean crop also varied according to the treatments. Under commercial farming, the NI treatment showed the lowest production costs of 3,429.18 and 3,565.17 $\mathrm{R} \$ \mathrm{ha}^{-1}$, respectively, in the states of Goiás and Minas Gerais. For both states, NfT had the highest production costs of 3,924.99 and 3,964.42 R $\$$ ha $^{-1}$, respectively (Table 3). Similarly, under family farming, the NI treatment showed the lowest production cost of 2,358.00 $\mathrm{R} \$ \mathrm{ha}^{-1}$ and $\mathrm{Nft}$, the highest of 2,977.81 R $\$$ ha $^{-1}$ in Goiás (Table 2).

Table 1. Common bean (Phaseolus vulgaris) grain yield when subjected to different nitrogen-supplying treatments in an irrigated commercial farming system in the states of Goiás and Minas Gerais, Brazil ${ }^{(1)}$.

\begin{tabular}{|c|c|c|c|c|}
\hline \multirow[t]{2}{*}{ Treatment $^{(2)}$} & \multicolumn{2}{|c|}{ Goiás $^{(3)}$} & \multicolumn{2}{|c|}{ Minas Gerais $^{(4)}$} \\
\hline & $\begin{array}{l}\text { Grain yield } \\
\left(\mathrm{kg} \mathrm{ha}^{-1}\right)\end{array}$ & $\begin{array}{l}\text { Equivalence in product } \\
\text { (bags of } 60 \mathrm{~kg} \mathrm{ha}^{-1} \text { ) }\end{array}$ & $\begin{array}{l}\text { Grain yield } \\
\left(\mathrm{kg} \mathrm{ha}^{-1}\right)\end{array}$ & $\begin{array}{l}\text { Equivalence in product } \\
\text { (bags of } 60 \mathrm{~kg} \mathrm{ha}^{-1} \text { ) }\end{array}$ \\
\hline NI & $2,351.15 b$ & $39.19 b$ & $3,491.33 b$ & $58.19 \mathrm{~b}$ \\
\hline NfT & $2,927.59 a$ & $48.79 \mathrm{a}$ & $3,502.03 b$ & $58.37 \mathrm{~b}$ \\
\hline Rt & $2,698.26 \mathrm{a}$ & $44.97 \mathrm{a}$ & $3,378.23 b$ & $56.30 \mathrm{~b}$ \\
\hline $\mathrm{Rt}+\mathrm{Ab} 1 \mathrm{~s}$ & $2,730.45 \mathrm{a}$ & $45.51 \mathrm{a}$ & $3,480.40 \mathrm{~b}$ & $58.01 \mathrm{~b}$ \\
\hline $\mathrm{Rt}+\mathrm{Ab} 2 \mathrm{~s}$ & $2,882.96 \mathrm{a}$ & $48.05 \mathrm{a}$ & $3,608.39 b$ & $60.14 b$ \\
\hline $\mathrm{Rt}+\mathrm{Ab} 2 \mathrm{p}$ & $2,835.98 \mathrm{a}$ & $47.27 \mathrm{a}$ & $3,786.30 \mathrm{a}$ & $63.11 \mathrm{a}$ \\
\hline $\mathrm{Rt}+\mathrm{Ab} 3 \mathrm{p}$ & $3,149.35 \mathrm{a}$ & $52.49 \mathrm{a}$ & $4,036.22 \mathrm{a}$ & $67.27 \mathrm{a}$ \\
\hline Average & $2,796.53$ & 46.61 & $3,611.84$ & 60.20 \\
\hline
\end{tabular}

Pesq. agropec. bras., Brasília, v.55, e01532, 2020

DOI: 10.1590/S1678-3921.pab2020.v55.01532 
The production cost of NfT in the commercial and family farming systems was about 5.0 (Table 3) and $8.5 \%$ (Table 2) higher than those of the Rt+Ab3p treatment, respectively. This occurs because the use of $\mathrm{N}$ fertilizers, as urea, represents an expressive percentage of production costs and may vary according to several factors. In their study, Gerlach et al. (2013) observed that the application of a dose equivalent to 90 $\mathrm{kg} \mathrm{ha}^{-1} \mathrm{~N}$ represented $14 \%$ of the total operational cost.

The gross revenue also differed among the treatments. Under commercial farming, the lowest gross revenue was found for the NI treatment in Goiás, and the greatest values were obtained for $\mathrm{Rt}+\mathrm{Ab} 2 \mathrm{p}$ and $\mathrm{Rt}+\mathrm{Ab} 3 \mathrm{p}$ in Minas Gerais (Table 3). Under family farming, $\mathrm{Rt}+\mathrm{Ab} 3 \mathrm{p}$ resulted in the best gross revenue (Table 2). The net revenue values, obtained by subtracting the production cost from the gross revenue and evaluated only for commercial farming, were higher for the Rt+Ab2s and $\mathrm{Rt}+\mathrm{Ab} 3 \mathrm{p}$ treatments in both Goiás and Minas Gerais.

The average production costs in the state of Minas Gerais were higher than those in Goiás, considering the product equivalence of 4 bags of $60 \mathrm{~kg} \mathrm{ha}^{-1}$ each. The average gross revenue was also higher, reaching 12 bags of $60 \mathrm{~kg} \mathrm{ha}^{-1}$. The net income in Minas Gerais was, on average, of 29 bags of $60 \mathrm{~kg} \mathrm{ha}^{-1}$, which was also higher than that in Goiás, of 19 bags of $60 \mathrm{~kg} \mathrm{ha}^{-1}$ (Table 3). The net revenue of $\mathrm{Rt}+\mathrm{Ab} 3 \mathrm{p}$ was greater than that of the NfT treatment with $80 \mathrm{~kg} \mathrm{ha}^{-1} \mathrm{~N}$; however, in some instances, the use of rhizobial inoculation plus $20 \mathrm{~kg} \mathrm{ha}^{-1} \mathrm{~N}$ results in a net revenue similar to that of the application of $160 \mathrm{~kg} \mathrm{ha}^{-1} \mathrm{~N}$ (Pelegrin et al., 2009).

The gross revenue seems to have significantly affected the benefit-cost ratio, which followed a similar pattern. In the state of Goiás, under commercial farming, the lowest benefit-cost ratio was observed for the NI treatment, while, in Minas Gerais, the highest value was obtained for $\mathrm{Rt}+\mathrm{Ab3p}$ (Table 3). Under family farming, both NfT and Rt+Ab3p presented the highest benefit-cost ratio (Table 2).

The economic balance showed that, under commercial farming in the state of Goiás, the gross revenue increased from 14.76 to $33.95 \%$ for $\mathrm{Rt}$ and $\mathrm{Rt}+\mathrm{Ab} 3 \mathrm{p}$, respectively, compared with that of the NI control. Considering that the production cost of these same treatments varied from 0.95 to $5.17 \%$, respectively, the best marginal benefit was around 12 bags of $60 \mathrm{~kg} \mathrm{ha}^{-1}$, resulting in a rate of return of $89.6 \%$ (Table 4). In Minas Gerais, the gross revenue varied from -1.89 to $9.08 \%$ for $\mathrm{Rt}$ and $\mathrm{Rt}+\mathrm{Ab3p}$, respectively. Taking into account that the production cost varied from 0.03 to $6.03 \%$ for Rt and $\mathrm{R} t+\mathrm{Ab} 3 \mathrm{p}$, respectively, the best marginal benefit was of around 7 bags of $60 \mathrm{~kg} \mathrm{ha}^{-1}$, resulting in a rate of return of $113.7 \%$ for the state.

Likewise, under family farming, the lowest increase of $2.53 \%$ in the gross revenue was found for the Rt treatment. However, greater increases of 56.67 and $56.28 \%$ were observed for NfT and Rt+Ab3p,

Table 2. Economic analysis of common bean (Phaseolus vulgaris) grown in an irrigated family farming system, when subjected to different nitrogen-supplying treatments in the municipality of Goianésia, in the state of Goiás, Brazil(1).

\begin{tabular}{|c|c|c|c|c|c|c|c|c|c|}
\hline \multirow[t]{3}{*}{ Treatment $^{(2)}$} & \multicolumn{9}{|c|}{ Economic indicator } \\
\hline & \multicolumn{2}{|c|}{ Grain yield } & \multicolumn{2}{|c|}{ Production cost } & \multicolumn{2}{|c|}{ Gross revenue } & \multicolumn{2}{|c|}{ Net revenue } & \multirow{2}{*}{$\begin{array}{l}\text { Benefit-cos } \\
\text { ratio }^{(3)}\end{array}$} \\
\hline & $\left(\mathrm{kg} \mathrm{ha}^{-1}\right)$ & $\begin{array}{c}\text { (bags of } \\
\left.60 \mathrm{~kg} \mathrm{ha}^{-1}\right)\end{array}$ & $\left(\mathrm{R} \$\right.$ ha $\left.^{-1}\right)$ & $\begin{array}{c}\text { (bags of } \\
\left.60 \mathrm{~kg} \mathrm{ha}^{-1}\right)\end{array}$ & $\left(\mathrm{R} \$ h^{-1}\right)$ & $\begin{array}{c}\text { (bags of } \\
\left.60 \mathrm{~kg} \mathrm{ha}^{-1}\right) \\
\end{array}$ & $\left(\mathrm{R} \$ \mathrm{ha}^{-1}\right)$ & $\begin{array}{c}\text { (bags of } \\
\left.60 \mathrm{~kg} \mathrm{ha}^{-1}\right) \\
\end{array}$ & \\
\hline NI & $1,499.65 \mathrm{~b}$ & $24.99 \mathrm{~b}$ & $2,358.00$ & 29.99 & $1,965.04 \mathrm{~b}$ & $24.99 \mathrm{~b}$ & $-392.96 b$ & $-5.00 \mathrm{~b}$ & $0.83 \mathrm{~b}$ \\
\hline NfT & $2,349.55 \mathrm{a}$ & $39.16 \mathrm{a}$ & $2,977.81$ & 37.88 & $3,078.69 \mathrm{a}$ & $39.16 \mathrm{a}$ & $100.88 \mathrm{a}$ & $1.28 \mathrm{a}$ & $1.03 \mathrm{a}$ \\
\hline Rt & $1,537.55 \mathrm{~b}$ & $25.63 \mathrm{~b}$ & $2,404.12$ & 30.58 & $2,014.70 \mathrm{~b}$ & $25.63 \mathrm{~b}$ & $-389.42 b$ & $-4.95 b$ & $0.84 \mathrm{~b}$ \\
\hline $\mathrm{Rt}+\mathrm{Ab} 1 \mathrm{~s}$ & $1,598.60 \mathrm{~b}$ & $26.64 \mathrm{~b}$ & $2,438.67$ & 31.02 & $2,094.70 \mathrm{~b}$ & $26.64 \mathrm{~b}$ & $-343.97 b$ & $-4.38 b$ & $0.86 \mathrm{~b}$ \\
\hline $\mathrm{Rt}+\mathrm{Ab} 2 \mathrm{~s}$ & $1,791.70 \mathrm{~b}$ & $29.86 \mathrm{~b}$ & $2,477.04$ & 31.51 & $2,347.72 b$ & $29.86 \mathrm{~b}$ & $-129.32 b$ & $-1.64 b$ & $0.95 \mathrm{~b}$ \\
\hline $\mathrm{Rt}+\mathrm{Ab} 2 \mathrm{p}$ & $1,610.47 \mathrm{~b}$ & $26.84 \mathrm{~b}$ & $2,492.79$ & 31.71 & $2,110.25 \mathrm{~b}$ & $26.84 \mathrm{~b}$ & $-382.54 \mathrm{~b}$ & $-4.87 \mathrm{~b}$ & $0.85 \mathrm{~b}$ \\
\hline $\mathrm{Rt}+\mathrm{Ab} 3 \mathrm{p}$ & $2,343.70 \mathrm{a}$ & $39.06 \mathrm{a}$ & $2,722.15$ & 34.62 & $3,071.03 \mathrm{a}$ & $39.06 \mathrm{a}$ & $348.88 \mathrm{a}$ & $4.44 \mathrm{a}$ & $1.13 \mathrm{a}$ \\
\hline
\end{tabular}

${ }^{(1)}$ Means followed by equal letters, in the columns, do not differ by Scott-Knott's test, at $5 \%$ probability. ${ }^{(2)} \mathrm{NI}$, non-inoculated control; NfT, fertilization with $80 \mathrm{~kg} \mathrm{ha}^{-1} \mathrm{~N}$ as urea (178 kg ha-1); Rt, seed inoculation with two doses of Rhizobium tropici; Rt $+\mathrm{Abls}$, seed inoculation with two doses of $R$. tropici and one dose of Azospirillum brasilense; $\mathrm{Rt}+\mathrm{Ab} 2 \mathrm{~s}$, seed inoculation with two doses of $R$. tropici and two doses of $A$. brasilense; $\mathrm{Rt}+\mathrm{Ab} 2 \mathrm{p}$, seed inoculation with two doses of $R$. tropici plus spraying of two doses of $A$. brasilense on plants; and Rt+Ab3p, seed inoculation with two doses of $R$. tropici plus spraying of three doses of $A$. brasilense on plants. ${ }^{(3)}$ Based on the prices paid for production factors, updated by the general price index of Fundação Getúlio Vargas (FGV) (base: April $2015=1.00$ ), and on the prices received by the common bean producers during harvest, updated by the general price index of FGV (base: September $2015=1.00$ ). Source: results based on agronomic data from Souza \& Ferreira (2017). 
respectively. Considering that the production cost varied from 12.57 to $5.17 \%$ for $\mathrm{NfT}$ and $\mathrm{Rt}+\mathrm{Ab} 3 \mathrm{p}$, respectively, the marginal benefit of $\mathrm{Rt}+\mathrm{Ab3p}$ was greater than that of NfT, resulting in a rate of return of 3.39 and $12.82 \%$ due to each treatment (Table 5).

In the state of Goiás, common bean responded positively to the use of nitrogen, Rt inoculation, and
$\mathrm{Rt}+\mathrm{Ab}$ co-inoculation, reflecting in yield increases, which provided greater economic gains. The $\mathrm{Rt}+\mathrm{Ab} 3 \mathrm{p}$ treatment effectively increased the gross revenue in 13.3 bags of $60 \mathrm{~kg} \mathrm{ha}^{-1}$, which represents a relative gain of about $34 \%$ compared with NI; this increase was caused by an additional cost equivalent to 1.36 bag of $60 \mathrm{~kg} \mathrm{ha}^{-1}$. Ndakidemi et al. (2006) performed

Table 3. Economic analysis of common bean (Phaseolus vulgaris) grown in an irrigated commercial farming system, when subjected to different nitrogen-supplying treatments in the states of Goiás and Minas Gerais, Brazil ${ }^{(1)}$.

\begin{tabular}{|c|c|c|c|c|}
\hline \multirow[t]{2}{*}{ Treatment $^{(2)}$} & \multicolumn{2}{|c|}{ Goiás ${ }^{(3)}$} & \multicolumn{2}{|c|}{ Minas Gerais $^{(4)}$} \\
\hline & $\begin{array}{c}\text { Value } \\
\left(\mathrm{R} \$ \mathrm{ha}^{-1}\right)\end{array}$ & $\begin{array}{l}\text { Equivalence in product } \\
\left.\text { (bags of } 60 \mathrm{~kg} \mathrm{ha}^{-1}\right)\end{array}$ & $\begin{array}{c}\text { Value } \\
\left(\mathrm{R} \$ \text { ha }^{-1}\right)\end{array}$ & $\begin{array}{l}\text { Equivalence in product } \\
\quad\left(\text { bags of } 60 \mathrm{~kg} \mathrm{ha}^{-1}\right)\end{array}$ \\
\hline & \multicolumn{4}{|c|}{ Production cost } \\
\hline NI & $3,429.18$ & 26.33 & $3,565.17$ & 29.69 \\
\hline NfT & $3,924.99$ & 29.64 & $3,964.42$ & 33.01 \\
\hline Rt & $3,521.75$ & 26.58 & $3,566.85$ & 29.70 \\
\hline $\mathrm{Rt}+\mathrm{Ab} 1 \mathrm{~s}$ & $3,521.43$ & 26.76 & $3,609.70$ & 30.06 \\
\hline $\mathrm{Rt}+\mathrm{Ab} 2 \mathrm{~s}$ & $3,588.27$ & 26.88 & $3,643.08$ & 30.34 \\
\hline $\mathrm{Rt}+\mathrm{Ab} 2 \mathrm{p}$ & $3,644.08$ & 27.29 & $3,719.71$ & 30.98 \\
\hline \multirow[t]{2}{*}{$\mathrm{Rt}+\mathrm{Ab} 3 \mathrm{p}$} & $3,715.68$ & 27.69 & $3,779.93$ & 31.48 \\
\hline & \multicolumn{4}{|c|}{ Gross revenue } \\
\hline NI & $5,102.79 b$ & $39.19 b$ & $6,987.32 b$ & $58.19 \mathrm{~b}$ \\
\hline NfT & $6,461.69 \mathrm{a}$ & $48.79 \mathrm{a}$ & $7,008.73 b$ & $58.37 \mathrm{~b}$ \\
\hline Rt & $5,958.08 \mathrm{a}$ & $44.97 \mathrm{a}$ & $6,760.96 b$ & $56.30 \mathrm{~b}$ \\
\hline $\mathrm{Rt}+\mathrm{Ab} 1 \mathrm{~s}$ & $5,988.12 \mathrm{a}$ & $45.51 \mathrm{a}$ & $6,965.44 \mathrm{~b}$ & $58.01 \mathrm{~b}$ \\
\hline $\mathrm{Rt}+\mathrm{Ab} 2 \mathrm{~s}$ & $6,414.71 \mathrm{a}$ & $48.05 \mathrm{a}$ & $7,221.59 \mathrm{~b}$ & $60.14 b$ \\
\hline $\mathrm{Rt}+\mathrm{Ab} 2 \mathrm{p}$ & $6,312.19 \mathrm{a}$ & $47.27 \mathrm{a}$ & $7,577.65 \mathrm{a}$ & $63.11 \mathrm{a}$ \\
\hline \multirow[t]{2}{*}{$\mathrm{Rt}+\mathrm{Ab} 3 \mathrm{p}$} & $7,042.80 \mathrm{a}$ & $52.49 \mathrm{a}$ & $8,077.81 \mathrm{a}$ & $67.27 \mathrm{a}$ \\
\hline & \multicolumn{4}{|c|}{ Net revenue } \\
\hline NI & $1,673.61 \mathrm{c}$ & $12.85 \mathrm{c}$ & $3,422.15 b$ & $28.50 \mathrm{~b}$ \\
\hline NfT & $2,536.70 \mathrm{~b}$ & $19.16 \mathrm{~b}$ & $3,044.31 \mathrm{~b}$ & $25.35 \mathrm{~b}$ \\
\hline Rt & $2,436.33 b$ & $18.39 \mathrm{~b}$ & $3,194.12 b$ & $26.60 \mathrm{~b}$ \\
\hline $\mathrm{Rt}+\mathrm{Ab} 1 \mathrm{~s}$ & $2,466.69 b$ & $18.75 \mathrm{~b}$ & $3,355.74 b$ & $27.95 b$ \\
\hline $\mathrm{Rt}+\mathrm{Ab} 2 \mathrm{~s}$ & $2,826.44 \mathrm{a}$ & $21.17 \mathrm{a}$ & $3,578.52 b$ & $29.80 \mathrm{~b}$ \\
\hline $\mathrm{Rt}+\mathrm{Ab} 2 \mathrm{p}$ & $2,668.11 b$ & $19.98 \mathrm{~b}$ & $3,857.94 \mathrm{a}$ & $32.13 a$ \\
\hline \multirow[t]{2}{*}{$\mathrm{Rt}+\mathrm{Ab} 3 \mathrm{p}$} & $3,327.12 \mathrm{a}$ & $24.80 \mathrm{a}$ & $4,297.88 \mathrm{a}$ & $35.79 \mathrm{a}$ \\
\hline & \multicolumn{4}{|c|}{ Benefit-cost ratio $^{(5)}$} \\
\hline NI & \multicolumn{2}{|c|}{$1.49 \mathrm{~b}$} & \multicolumn{2}{|c|}{$1.96 \mathrm{~b}$} \\
\hline NfT & \multicolumn{2}{|c|}{$1.65 \mathrm{a}$} & \multicolumn{2}{|c|}{$1.77 \mathrm{~b}$} \\
\hline Rt & \multicolumn{2}{|c|}{$1.69 \mathrm{a}$} & \multicolumn{2}{|c|}{$1.90 \mathrm{~b}$} \\
\hline $\mathrm{Rt}+\mathrm{Ab} 1 \mathrm{~s}$ & \multicolumn{2}{|c|}{$1.70 \mathrm{a}$} & \multicolumn{2}{|c|}{$1.93 b$} \\
\hline $\mathrm{Rt}+\mathrm{Ab} 2 \mathrm{~s}$ & \multicolumn{2}{|c|}{$1.79 \mathrm{a}$} & \multicolumn{2}{|c|}{$1.98 \mathrm{~b}$} \\
\hline $\mathrm{Rt}+\mathrm{Ab} 2 \mathrm{p}$ & \multicolumn{2}{|c|}{$1.73 \mathrm{a}$} & \multicolumn{2}{|c|}{$2.04 \mathrm{~b}$} \\
\hline $\mathrm{Rt}+\mathrm{Ab} 3 \mathrm{p}$ & \multicolumn{2}{|c|}{$1.90 \mathrm{a}$} & \multicolumn{2}{|c|}{$2.14 \mathrm{a}$} \\
\hline
\end{tabular}

${ }^{(1)}$ Means followed by equal letters, in the columns, do not differ by Scott-Knott's test, at $5 \%$ probability. ${ }^{(2)} \mathrm{NI}$, non-inoculated control; NfT, fertilization with $80 \mathrm{~kg} \mathrm{ha}^{-1} \mathrm{~N}$ as urea $\left(178 \mathrm{~kg} \mathrm{ha}^{-1}\right)$; Rt, seed inoculation with two doses of Rhizobium tropici; Rt $+\mathrm{Abls}$, seed inoculation with two doses of $R$. tropici and one dose of Azospirillum brasilense; $\mathrm{Rt}+\mathrm{Ab} 2 \mathrm{~s}$, seed inoculation with two doses of $R$. tropici and two doses of $A$. brasilense; $\mathrm{Rt}+\mathrm{Ab} 2 \mathrm{p}$, seed inoculation with two doses of $R$. tropici plus spraying of two doses of $A$. brasilense on plants; and Rt+Ab3p, seed inoculation with two doses of $R$. tropici plus spraying of three doses of $A$. brasilense on plants. ${ }^{(3)}$ Average of the Itaberaí, Santo Antônio de Goiás, and Cristalina municipalities of the state of Goiás. ${ }^{(4)}$ Average of the Unaí and Paracatu municipalities of the state of Minas Gerais. ${ }^{(5)}$ Based on the prices paid for production factors, updated by the general price index of Fundação Getúlio Vargas (FGV) (base: April $2015=1.00$ ), and on the prices received by the common bean producers during harvest, updated by the general price index of FGV (base: September $2015=1.00$ ). Source: results based on agronomic data from Souza \& Ferreira (2017). 
an economic analysis in northern Tanzania and found that, compared with the uninoculated control, the inoculation of common bean increased grain yield, translating into a dollar profit increase of 66 and 92\% in the Moshi and Rombo districts, respectively.

In the present study, the $\mathrm{R}+\mathrm{Ab} 3 \mathrm{p}$ treatment showed the best economic performance of co-inoculation. In the state of Goiás, it resulted in a marginal revenue of almost 12 bags of $60 \mathrm{~kg} \mathrm{ha}^{-1}$, at a rate of return of about $90 \%$ on the investment done within the cropping system (Table 4). In Minas Gerais, it resulted in a marginal revenue of about 7 bags of $60 \mathrm{~kg} \mathrm{ha}^{-1}$, at a rate of return of approximately $114 \%$. In the latter state, $\mathrm{R} t+\mathrm{Ab} 3 \mathrm{p}$ also caused an effective increase of 9.08 bags of $60 \mathrm{~kg} \mathrm{ha}^{-1}$ in the gross revenue, representing a relative gain of about $16 \%$ compared with the NI treatment.

The relevance of Azospirillum sp. inoculation, in association with other microorganisms or coupled with mineral nitrogen fertilization, has been reported for many crops, including grasses. In a study on the effect of inoculation vs. nitrogen doses, Galindo et al. (2017) concluded that the inoculation with $A$. brasilense allows a more profitable corn (Zea mays L.) growth, regardless of the used nitrogen dose and source. The authors also found that grain yield is increased by the addition of $200 \mathrm{~kg} \mathrm{ha}^{-1} \mathrm{~N}$, in the form of conventional urea, coupled with the inoculation with $A$. brasilense; however, the highest economic return is obtained with $100 \mathrm{~kg} \mathrm{ha} \mathrm{h}^{-1} \mathrm{~N}$, as conventional urea, combined with inoculation.

The additional cost of using only nitrogen in the NfT treatment was equivalent to 7.88 bags of $60 \mathrm{~kg} \mathrm{ha}^{-1}$, with a marginal benefit of 6.28 bags of $60 \mathrm{~kg} \mathrm{ha}^{-1}$. Compared with the other co-inoculation treatments, $\mathrm{Rt}+\mathrm{Ab3p}$ was an advantageous exception, because, at an additional cost of 4.63 bags of $60 \mathrm{~kg} \mathrm{ha}^{-1}$, it allowed obtaining a marginal benefit of 9.44 bags of $60 \mathrm{~kg} \mathrm{ha}^{-1}$ and a profitability of $13 \%$ on the investment made (Table 5). Although the use of inoculants in family farming systems by smallholders is not usual, the interest in this technology is growing over the years,

Table 4. Economic balance of common bean (Phaseolus vulgaris) grown in an irrigated commercial farming system, when subjected to different nitrogen-supplying treatments in the states of Goiás and Minas Gerais, Brazil.

\begin{tabular}{|c|c|c|c|c|c|c|c|c|}
\hline \multirow[t]{3}{*}{ Treatment $^{(1)}$} & \multicolumn{8}{|c|}{ Economic indicator } \\
\hline & \multicolumn{2}{|c|}{ Gross revenue } & \multicolumn{4}{|c|}{ Production cost } & \multicolumn{2}{|c|}{ Economic viability } \\
\hline & $\begin{array}{l}\text { Equivalence in } \\
\text { product (bags } \\
\text { of } 60 \mathrm{~kg} \mathrm{ha}^{-1} \text { ) }\end{array}$ & $\begin{array}{l}\text { Increase }^{(2)} \\
\text { (bags of } \\
\left.60 \mathrm{~kg} \mathrm{ha}^{-1}\right)\end{array}$ & $\begin{array}{c}\text { Variation } \\
(\%)\end{array}$ & $\begin{array}{l}\text { Equivalence in } \\
\text { product (bags } \\
\text { of } 60 \mathrm{~kg} \mathrm{ha}^{-1} \text { ) }\end{array}$ & $\begin{array}{c}\text { Additional } \\
\text { costs }^{(2)}(\text { bags } \\
\left.\text { of } 60 \mathrm{~kg} \mathrm{ha}^{-1}\right)\end{array}$ & $\begin{array}{c}\text { Variation } \\
(\%)\end{array}$ & $\begin{array}{c}\text { Marginal benefit } \\
\text { (bags of } \\
\left.60 \mathrm{~kg} \mathrm{ha}^{-1}\right)\end{array}$ & $\begin{array}{c}\text { Rate of } \\
\text { return }^{(3)} \\
(\%)\end{array}$ \\
\hline & \multicolumn{8}{|c|}{ Goiás } \\
\hline NI & 39.19 & - & - & 26.33 & - & - & - & 48.8 \\
\hline NfT & 48.79 & 9.61 & 24.52 & 29.64 & 3.31 & 12.57 & 6.30 & 64.6 \\
\hline Rt & 44.97 & 5.79 & 14.76 & 26.58 & 0.25 & 0.95 & 5.54 & 69.2 \\
\hline $\mathrm{Rt}+\mathrm{Ab} 1 \mathrm{~s}$ & 45.51 & 6.32 & 16.13 & 26.76 & 0.43 & 1.63 & 5.89 & 70.1 \\
\hline $\mathrm{Rt}+\mathrm{Ab} 2 \mathrm{~s}$ & 48.05 & 8.86 & 22.62 & 26.88 & 0.55 & 2.09 & 8.31 & 78.8 \\
\hline $\mathrm{Rt}+\mathrm{Ab} 2 \mathrm{p}$ & 47.27 & 8.08 & 20.62 & 27.29 & 0.96 & 3.65 & 7.12 & 73.2 \\
\hline \multirow[t]{2}{*}{$\mathrm{Rt}+\mathrm{Ab} 3 \mathrm{p}$} & 52.49 & 13.30 & 33.95 & 27.69 & 1.36 & 5.17 & 11.94 & 89.6 \\
\hline & \multicolumn{8}{|c|}{ Minas Gerais } \\
\hline NI & 58.19 & - & - & 29.69 & - & - & - & 96.0 \\
\hline NfT & 58.37 & 0.18 & 0.31 & 33.01 & 3.32 & 11.18 & -3.14 & 76.8 \\
\hline Rt & 56.30 & -1.89 & -3.24 & 29.70 & 0.01 & 0.03 & -1.90 & 89.6 \\
\hline $\mathrm{Rt}+\mathrm{Ab} 1 \mathrm{~s}$ & 58.01 & -0.18 & -0.31 & 30.06 & 0.37 & 1.25 & -0.55 & 93.0 \\
\hline $\mathrm{Rt}+\mathrm{Ab} 2 \mathrm{~s}$ & 60.14 & 1.95 & 3.35 & 30.34 & 0.65 & 2.19 & 1.30 & 98.2 \\
\hline $\mathrm{Rt}+\mathrm{Ab} 2 \mathrm{p}$ & 63.11 & 4.92 & 8.45 & 30.98 & 1.29 & 4.34 & 3.63 & 103.7 \\
\hline $\mathrm{Rt}+\mathrm{Ab} 3 \mathrm{p}$ & 67.27 & 9.08 & 15.61 & 31.48 & 1.79 & 6.03 & 7.29 & 113.7 \\
\hline
\end{tabular}

${ }^{(1)} \mathrm{NI}$, non-inoculated control; NfT, fertilization with $80 \mathrm{~kg} \mathrm{ha}^{-1} \mathrm{~N}$ as urea $\left(178 \mathrm{~kg} \mathrm{ha}^{-1}\right)$; Rt, seed inoculation with two doses of Rhizobium tropici; Rt+Ab1s, seed inoculation with two doses of $R$. tropici and one dose of Azospirillum brasilense; Rt+Ab2s, seed inoculation with two doses of $R$. tropici and two doses of $A$. brasilense; $\mathrm{Rt}+\mathrm{Ab} 2 \mathrm{p}$, seed inoculation with two doses of $R$. tropici plus spraying of two doses of $A$. brasilense on plants; and Rt+Ab3p, seed inoculation with two doses of $R$. tropici plus spraying of three doses of $A$. brasilense on plants. ${ }^{(2)} Y$ ield increase and marginal costs of each treatment compared with the non-inoculated control $(\mathrm{NI}=100) .{ }^{(3)}$ Based on the prices paid for production factors, updated by the general price index of Fundação Getúlio Vargas (FGV) (base: April $2015=1.00$ ), and on the prices received by the common bean producers during harvest, updated by the general price index of FGV (base: September $2015=1.00$ ). 
Table 5. Economic balance of common bean (Phaseolus vulgaris) grown in an irrigated family farming system, when subjected to different nitrogen-supplying treatments in the municipality of Goianésia, in the state of Goiás, Brazil.

\begin{tabular}{|c|c|c|c|c|c|c|c|c|}
\hline \multirow[t]{3}{*}{ Treatment $^{(1)}$} & \multicolumn{8}{|c|}{ Economic indicator } \\
\hline & \multicolumn{3}{|c|}{ Gross revenue } & \multicolumn{3}{|c|}{ Production cost } & \multicolumn{2}{|c|}{ Economic viability } \\
\hline & $\begin{array}{c}\text { Equivalence in } \\
\text { product } \\
\text { (bags of } 60 \mathrm{~kg} \mathrm{ha}^{-1} \text { ) }\end{array}$ & $\begin{array}{l}\text { Increase }^{(2)} \\
\left(\text { bags of }^{-1}\right. \\
\left.60 \mathrm{~kg} \mathrm{ha}^{-1}\right)\end{array}$ & $\begin{array}{l}\text { Variation } \\
\quad(\%)\end{array}$ & $\begin{array}{c}\text { Equivalence in } \\
\text { product } \\
\text { (bags of } 60 \mathrm{~kg} \mathrm{ha}^{-1} \text { ) }\end{array}$ & $\begin{array}{l}\text { Additional costs } \\
\text { (bags of } 60 \mathrm{~kg} \mathrm{ha}^{-1} \text { ) }\end{array}$ & $\begin{array}{l}\text { Variation } \\
(\%)\end{array}$ & $\begin{array}{l}\text { Marginal benefit } \\
\text { (bags of } \\
\left.60 \mathrm{~kg} \mathrm{ha}^{-1}\right)\end{array}$ & $\begin{array}{l}\text { Rate of } \\
\text { return } \\
(\%)\end{array}$ \\
\hline NI & 24.99 & - & - & 29.99 & - & - & -5.00 & -16.66 \\
\hline NfT & 39.16 & 14.17 & 56.67 & 37.88 & 7.88 & 26.29 & 6.28 & 3.39 \\
\hline Rt & 25.63 & 0.63 & 2.53 & 30.58 & 0.59 & 1.96 & 0.05 & -16.20 \\
\hline $\mathrm{Rt}+\mathrm{Ab} 1 \mathrm{~s}$ & 26.64 & 1.65 & 6.60 & 31.02 & 1.03 & 3.42 & 0.62 & -14.10 \\
\hline $\mathrm{Rt}+\mathrm{Ab} 2 \mathrm{~s}$ & 29.86 & 4.87 & 19.47 & 31.51 & 1.51 & 5.05 & 3.35 & -5.22 \\
\hline $\mathrm{Rt}+\mathrm{Ab} 2 \mathrm{p}$ & 26.84 & 1.85 & 7.39 & 31.71 & 1.71 & 5.72 & 0.13 & -15.35 \\
\hline$R t+A b 3 p$ & 39.06 & 14.07 & 56.28 & 34.62 & 4.63 & 15.44 & 9.44 & 12.82 \\
\hline
\end{tabular}

(1)NI, non-inoculated control; NfT, fertilization with $80 \mathrm{~kg} \mathrm{ha}^{-1} \mathrm{~N}$ as urea (178 kg ha-1); Rt, seed inoculation with two doses of Rhizobium tropici; Rt $+\mathrm{Ab} 1 \mathrm{~s}$, seed inoculation with two doses of $R$. tropici and one dose of Azospirillum brasilense; Rt+Ab2s, seed inoculation with two doses of $R$. tropici and two doses of $A$. brasilense; $\mathrm{Rt}+\mathrm{Ab} 2 \mathrm{p}$, seed inoculation with two doses of $R$. tropici plus spraying of two doses of $A$. brasilense on plants; and Rt+Ab3p, seed inoculation with two doses of $R$. tropici plus spraying of three doses of $A$. brasilense on plants. ${ }^{(2)} Y$ ield increase and marginal costs of each treatment compared with the non-inoculated control $(\mathrm{NI}=00) .{ }^{(3)}$ Based on the prices paid for production factors, updated by the general price index of Fundação Getúlio Vargas (FGV) (base: April $2015=1.00$ ), and on the prices received by the common bean producers during harvest, updated by the general price index of FGV (base: September $2015=1.00$ ).

mostly in southern Africa (Giller et al., 2011), where the gross margin achieved by inoculant users was highly significant, reaching about US\$ 278 per hectare (Mutuma et al., 2014).

The results obtained in the present study are indicative of the importance of using $R$. tropici in the inoculation of common bean. In this line, Ndakidemi et al. (2006) found that inoculation increased the crop's profit in about 140 and $153 \%$ in the Moshi and Rombo districts, respectively, in northern Tanzania. In addition, the present study also showed that the coinoculation of $R$. tropici and A. brasilense increased the rate of return of the crop in about $30 \%$. Similarly, Galindo et al. (2018) reported that the co-inoculation with $A$. brasilense and Bradyrhizobium elkanii or Bradyrhizobium japonicum positively affected soybean [Glycine Max (L.) Merr.], resulting in a profitability index of about $64 \%$.

\section{Conclusions}

1. In commercial and family farming, the production cost when using nitrogen fertilizer is, respectively, 5.0 and $8.5 \%$ higher than that with the co-inoculation of two doses of Rhizobium tropici and three doses of Azospirillum brasilense in the Pérola cultivar of common bean (Phaseolus vulgaris).
2. In family farming, the co-inoculation of $R$. tropici with three doses of $A$. brasilense in common bean results in a profitability of $13 \%$.

3 . The net income of the co-inoculation treatments in the state of Minas Gerais is 20 bags per hectare in common bean higher than that of the same treatments in the state of Goiás, Brazil.

4. In commercial farming, the co-inoculation of two doses of $R$. tropici and three doses of $A$. brasilense in common bean has a return rate of $90 \%$ in Goiás and of $114 \%$ in Minas Gerais.

\section{References}

ARGAW, A.; MEKONNEN, E.; MULETA, D. Agronomic efficiency of $\mathrm{N}$ of common bean (Phaseolus vulgaris L.) in some representative soils of Eastern Ethiopia. Cogent Food \& Agriculture, v.1, art.1074790, 2015. DOI: https://doi.org/10.1080 /23311932.2015.1074790.

AVILA, A.F.D.; RODRIGUES, G.S.; VEDOVOTO, G.L. (Ed.). Avaliação dos impactos de tecnologias geradas pela Embrapa: metodologia de referência. Brasília: Embrapa Informação Tecnológica, 2008. 189p.

BÁRBARO, I.M.; BRANCALIÃO, S.R.; TICELLI, M.; MIGUEL, F.B.; SILVA, J.A.A. da. Técnica alternativa: co-inoculação de soja com Azospirillum e Bradyrhizobium visando incremento de produtividade. 2008. Available at: <http://www.infobibos.com/ Artigos/2008_4/coinoculacao/index.htm>. Accessed on: June 6 2019. 
BAYE, M.R. Economia de empresas e estratégias de negócios. 6.ed. Porto Alegre: AMGH, 2010. 656p.

BIRACHI, E.A.; OCHIENG, J.; WOZEMBA, D.; RURADUMA, C.; NIYUHIRE, M.C.; OCHIENG, D. Factors influencing smallholder farmers' bean production and supply to market in Burundi. African Crop Science Journal, v.19, p.335-342, 2011.

BRITO, L.F. de; PACHECO, R.S.; SOUZA FILHO, B.F. de; FERREIRA, E.P. de B.; STRALIOTTO, R.; ARAÚJO, A.P. Resposta do feijoeiro comum à inoculação com rizóbio e suplementação com nitrogênio mineral em dois biomas brasileiro. Revista Brasileira de Ciência do Solo, v.39, p.981-992, 2015. DOI: https://doi.org/10.1590/01000683rbcs20140322.

BRITO, M.de M.P.; MURAOKA, T.; SILVA, E.C. da. Contribuição da fixação biológica de nitrogênio, fertilizante nitrogenado e nitrogênio do solo no desenvolvimento de feijão e caupi. Bragantia, v.70, p.206-215, 2011. DOI: https://doi.org/10.1590/ S0006-87052011000100027.

EMBRAPA ARROZE FEIJÃO. Dados conjunturais da produção de feijão (Phaseolus vulgaris L.) e caupi (Vigna unguiculata L.) no Brasil (1985 a 2018): área, produção e rendimento. Available at: <http://www.cnpaf.embrapa.br/socioeconomia/index.htm>. Accessed on: June 12020.

FARINELLI, R.; LEMOS, L.B. Produtividade, eficiência agronômica, características nutricionais e tecnológicas do feijão adubado com nitrogênio em plantio direto e convencional. Bragantia, v.69, p.165-172, 2010. DOI: https://doi.org/10.1590/ S0006-87052010000100021.

FERREIRA, D.F. Sisvar: a computer statistical analysis system. Ciência e Agrotecnologia, v.35, p.1039-1042, 2011. DOI: https://doi.org/10.1590/S1413-70542011000600001.

GALINDO, F.S.; TEIXEIRA FILHO, M.C.M.; BUZETTI, S.; LUDKIEWICZ, M.G.Z.; ROSA, P.A.L.; TRITAPEPE, C.A. Technical and economic viability of co-inoculation with Azospirillum brasilense in soybean cultivars in the Cerrado. Revista Brasileira de Engenharia Agrícola e Ambiental, v.22, p.51-56, 2018. DOI: https://doi.org//10.1590/1807-1929/agriambi. v22n1p51-56.

GALINDO, F.S.; TEIXEIRA FILHO, M.C.M.; TARSITANO, M.A.A.; BUZETTI, S.; SANTINI, J.M.K.; LUDKIEWICZ, M.G.Z.; ALVES, C.J.; ARF, O. Economic analysis of corn inoculated with Azospirillum brasilense associated with nitrogen sources and doses. Semina: Ciências Agrárias, v.38, p.1749-1764, 2017. DOI: https://doi.org/10.5433/1679-0359.2017v38n4p1749.

GERLACH, G.A.X.; ARF, O.; CORSINI, D.C.D.C.; SILVA, J.C. da; COLETTI, A.J. Análise econômica da produção de feijão em função de doses de nitrogênio e coberturas vegetais. Pesquisa Agropecuária Tropical, v.43, p.42-49, 2013. DOI: https://doi.org/10.1590/S1983-40632013000100005.

GILLER, K.E.; MURWIRA, M.S.; DHLIWAYO, D.K.C.; MAFONGOYA, P.L.; MPEPEREKI, S. Soyabeans and sustainable agriculture in southern Africa. International
Journal of Agricultural Sustainability, v.9, p.50-58, 2011. DOI: https://doi.org/10.3763/ijas.2010.0548.

GUIDUCCI, R. do C.N.; LIMA FILHO, J.R. de; MOTA, M.M. Viabilidade econômica de sistemas de produção agropecuários: metodologia e estudos de caso. Brasília: Embrapa, 2012. 535p.

HUNGRIA, M.; NOGUEIRA, M.A.; ARAUJO, R.S. Coinoculation of soybeans and common beans with rhizobia and azospirilla: strategies to improve sustainability. Biology and Fertility of Soils, v.49, p.791-801, 2013. DOI: https://doi.org/10.1007/s00374-012-0771-5.

MUTUMA, S.P.; OKELLO, J.J.; KARANJA, N.K.; WOOMER, P.L. Smallholder farmers' use and profitability of legume inoculants in western Kenya. African Crop Science Journal, v.22, p.205-213, 2014.

NDAKIDEMI, P.A.; DAKORA, F.D.; NKONYA, E.M.; RINGO, D.; MANSOOR, H. Yield and economic benefits of common bean (Phaseolus vulgaris) and soybean (Glycine max) inoculation in northern Tanzania. Australian Journal of Experimental Agriculture, v.46, p.571-577, 2006. DOI: https://doi.org/10.1071/ EA03157.

PELEGRIN, R. de; MERCANTE, F.M.; OTSUBO, I.M.N.; OTSUBO, A.A. Resposta da cultura do feijoeiro à adubação nitrogenada e à inoculação com rizóbio. Revista Brasileira de Ciência do Solo, v.33, p.219-226, 2009. DOI: https://doi.org/10.1590/S0100-06832009000100023.

PERES, A.R.; RODRIGUES, R.A.F.; ARF, O.; PORTUGAL, J.R.; CORSINI, D.C.D.C. Co-inoculation of Rhizobium tropici and Azospirillum brasilense in common beans grown under two irrigation depths. Revista Ceres, v.63, p.198-207, 2016. DOI: https://doi.org/10.1590/0034-737X201663020011.

SILVA, O.F. da; WANDER, A.E.; DIDONET, A.D. Sistema e custo de produção de feijão-comum de segunda safra para agricultura familiar em Goiás. In: GUIDUCCI, R. do C.N.; LIMA FILHO, J.R. de; MOTA, M.M. (Eds.). Viabilidade econômica de sistemas de produção agropecuários: metodologia e estudos de caso. Brasília: Embrapa, 2012. p.509-535.

SOARES, B.L.; FERREIRA, P.A.A.; RUFINI, M.; MARTINS, F.A.D.; OLIVEIRA, D.P.; REIS, R.P.; ANDRADE, M.J.B. de; MOREIRA, F.M. de S. Agronomic and economic efficiency of common-bean inoculation with rhizobia and mineral nitrogen fertilization. Revista Brasileira de Ciência doSolo, v.40, e0150235, 2016. DOI:_https://doi.org/10.1590/18069657rbcs20150235.

SORATO, R.P.; CATUCHI, T.A.; SOUZA, E. de F.C. de; GARCIA, J.L.N. Plant density and nitrogen fertilization on common bean nutrition and yield. Revista Caatinga, v.30, p.670678, 2017. DOI: https://doi.org/10.1590/1983-21252017v30n315rc.

SOUZA, J.E.B. de; FERREIRA, E.P. de B. Improving sustainability of common bean production systems by co-inoculating rhizobia and azospirilla. Agriculture, Ecosystems \& Environment, v.237, p.250-257, 2017. DOI: https://doi.org/10.1016/j.agee.2016.12.040. 